\title{
Evaluation of the Shear Strength of Perfobond Rib Connectors in Ultra High Performance Concrete
}

\author{
Jae Yoon Kang*, Jong Sup Park, Woo Tai Jung, Moon Seoung Keum \\ Structural Engineering Research Division, Korea Institute of Civil Engineering and Building Technology, \\ Goyang, Korea \\ Email: “iykang@kict.re.kr, jspark1@kict.re.kr, woody@kict.re.kr, moonseoung@kict.re.kr
}

Received 26 September 2014; revised 24 October 2014; accepted 15 November 2014

Copyright (C) 2014 by authors and Scientific Research Publishing Inc.

This work is licensed under the Creative Commons Attribution International License (CC BY). http://creativecommons.org/licenses/by/4.0/

(c) (i) Open Access

\section{Abstract}

Since the previous strength prediction models for the perfobond rib connector were proposed based upon the results of push-out tests conducted on concretes with compressive strength below $50 \mathrm{MPa}$, push-out test is performed on perfobond shear connectors applying ultra high performance concretes with compressive strength higher than $80 \mathrm{MPa}$ to evaluate their shear resistance. The test variables are chosen to be the diameter and number of dowel holes and, the change in the shear strength of the perfobond rib connector is examined with respect to the strength of two types of UHPC: steel fiber-reinforced concrete with compressive strength of $180 \mathrm{MPa}$ and concrete without steel fiber with compressive strength of $80 \mathrm{MPa}$. The test results reveal that higher concrete strength and larger number of holes increased the shear strength, and that higher increase rate in the shear strength was achieved by the dowel action. The comparison with the predictions obtained by the previous models shows that the experimental results are close to the values given by the model proposed by Oguejiofor and Hosain [1].

\section{Keywords}

Perfobond Rib Connector, Ultra High Performance Concrete, Push-Out Test, Shear Strength

\section{Introduction}

The most popular shear connector used in composite structures is the headed stud. However, this connector is vulnerable to fatigue and is prone to sudden failure through breakage in the weld of the stud. Accordingly, pre-

\footnotetext{
${ }^{*}$ Corresponding author.
}

How to cite this paper: Kang, J.Y., Park, J.S., Jung, W.T. and Keum, M.S. (2014) Evaluation of the Shear Strength of Perfobond Rib Connectors in Ultra High Performance Concrete. Engineering, 6, 989-999. 
ference has been recently shifted to stiffer shear connectors like the perfobond rib. The perfobond rib is fabricated by boring a number of holes in a steel plate so as realize a structure with improved shear performance by exploiting the dowel action generated by concrete placed in the holes.

Figure 1 illustrates the mechanical elements resisting shear in the perfobond rib connector involving the shear resistance in the concrete dowel, the shear resistance of the transverse steel reinforcement and, the concrete bearing pressure over the whole steel plate.

\section{Review of Strength Prediction Models for Perfobond Rib Connector}

Oguejiofor and Hosain [1], Medberry and Shahrooz [2], Verissimo et al. [3], Al-Darzi et al. [4] and, Ahn et al. [5] conducted push-out test to propose different empirical models evaluating the strength of the perfobond rib connector. Ushijima et al. [6] and Cho et al. [7] suggested evaluation formulae accounting for the contribution of the concrete dowel action to the shear resistance in the perfobond rib connector. In Table 1 arranging these models, it can be seen that the shear is predicted by summing up distinctive terms relating separately the shear resistance contributed by the end bearing pressure, by the concrete dowel and, by the transverse steel reinforcement.

Figure 2 compares the shear strength predictions of each model assuming a perfobond rib with plate thickness $t=15 \mathrm{~mm}$, plate height $h=100 \mathrm{~mm}$ and, hole diameter $D=30 \mathrm{~mm}$. The comparison shows that the model of Oguejiofor and Hosain [1] predicts relatively larger strength whereas Verissimo et al. [3] provides a lower bound and, the formula of Ahn et al. [5] gives median prediction.

Moreover, Figure 3 compares the shear strength calculated for concrete with compressive strength of $80 \mathrm{MPa}$. It can be seen that the shear strength computed for the perfobond rib connector is approximately 1.6 to 3.7 times larger than that of the stud defined in Eurocode.

It is noteworthy that most of the prediction models were established based upon push-out test for concrete with compressive strength running around $27 \mathrm{MPa}$. Since only Ahn et al. [5] considered concretes with com-

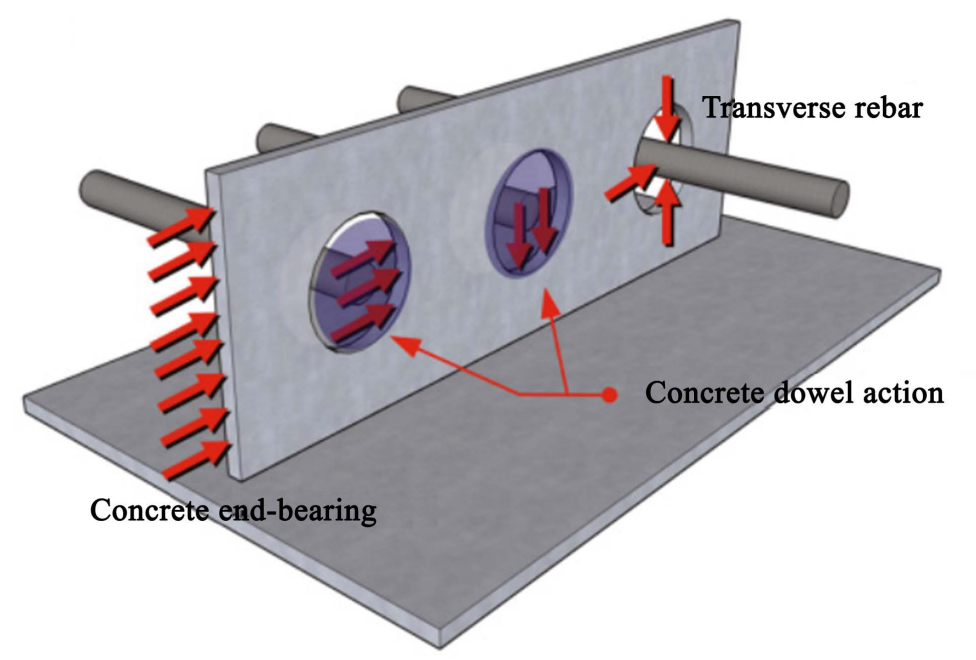

Figure 1. Shear-resisting mechanism of perfobond rib.

Table 1. Strength prediction models for perfobond rib.

\begin{tabular}{cc}
\hline Authors & Strength prediction models \\
\hline Oguejiofor and Hosain [1] & $q_{u}=4.5 h_{s c} t_{s c} f_{c k}+0.91 A_{r r} f_{y}+3.31 n D^{2} \sqrt{f_{c k}}$ \\
Medberry and Shahrooz [2] & $q_{u}=0.747 b h \sqrt{f_{c k}}+0.413 b_{f} L_{c}+0.9 A_{r r} f_{y}+1.66 n \pi\left(\frac{1}{2} D\right)^{2} \sqrt{f_{c k}}$ \\
Verissimo et al. [3] & $q_{u}=4.04\left(h_{s c} / b\right) h_{s c} t_{s c} f_{c k}+2.37 n D^{2} \sqrt{f_{c k}}+0.16 A_{c c} \sqrt{f_{c k}}+31.85 \times 10^{6}\left(A_{r r} / A_{c c}\right)$ \\
Al-Darzi et al. [4] & $q_{u}=255.31+7.62 \times 10^{-4} h_{s c} t_{s c} f_{c k}-7.59 \times 10^{7} A_{r r} f_{y}+2.53 \times 10^{-3} A_{s c} \sqrt{f_{c k}}$ \\
Ahn et al. [5] & $q_{u}=3.14 h_{s c} t_{s c} f_{c k}+1.21 A_{r r} f_{y}+3.79 n \pi\left(\frac{1}{2} D\right)^{2} \sqrt{f_{c k}}$ \\
\hline
\end{tabular}




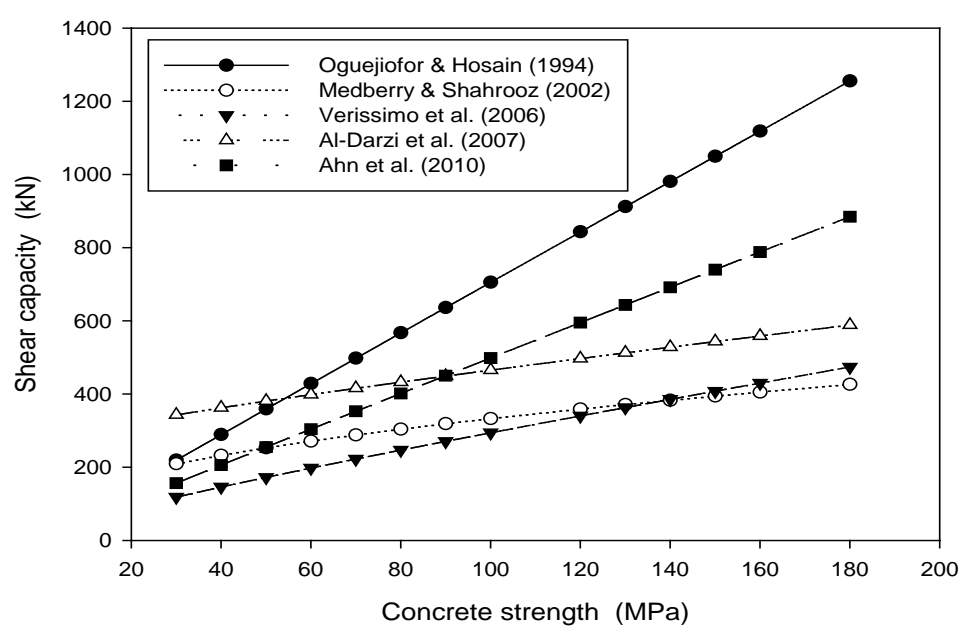

Figure 2. Comparison of shear strength of perfobond rib connector predicted by previous models.

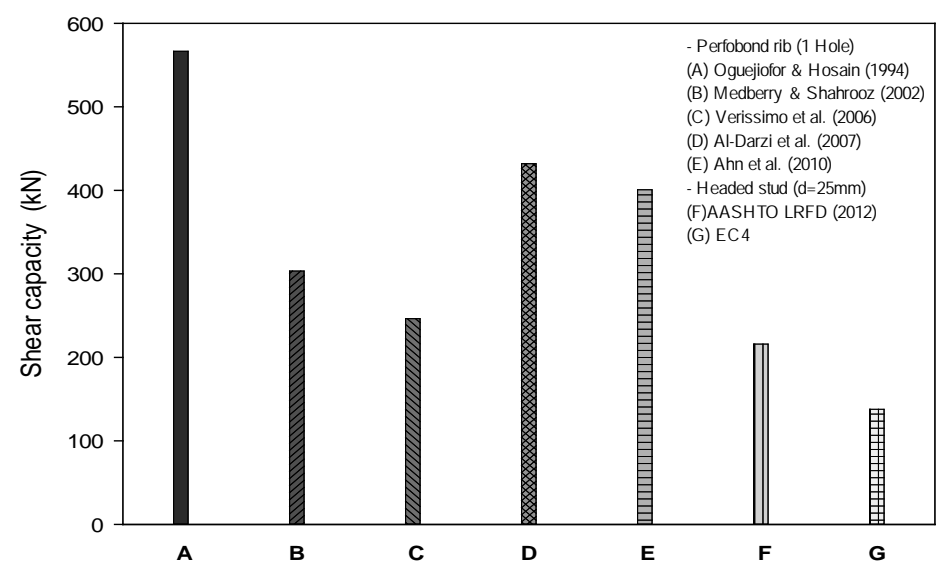

Figure 3. Comparison of shear strength computed for concrete with compressive strength of $80 \mathrm{MPa}$.

pressive strength up to $50 \mathrm{MPa}$ in their experiments, the applicability of these shear connector strength prediction models for high strength concrete and, particularly steel fiber-reinforced ultra high strength concrete, should be examined experimentally.

On the behavior of stud connector in high strength concrete, An and Cederwall [8] conducted push-out tests to understand the strength of a stud depends on the concrete property with compressive strength of $100 \mathrm{MPa}$. They concluded that the stud in the high strength concrete tends to be sheared-off from the steel beam at the maximum load, while it shows very ductile behavior of stud in the normal strength concrete. As headed studs don't have enough shear capacity in high strength concrete, a continuous shear connectors such as puzzle strip has been suggested. Hegger et al. [9] investigated load-carrying behavior of puzzle strip connectors in ultra high performance concrete with compressive strength of $180 \mathrm{MPa}$, and they reported that the continuous type of shear connectors like the puzzle strip are appropriate for the high strength concrete as it is capable of carrying high shear loads with an appropriate ductility.

\section{Push-Out Test of Perfobond Rib Connector Using Ultra High Performance Concrete}

\subsection{Objectives of Test}

The previous strength prediction models proposed for the perfobond rib connector were established based on 
experiments conducted on concretes with compressive strength lower than $50 \mathrm{MPa}$. Therefore, the establishment of a strength prediction model for the perfobond rib connector using ultra high performance concrete (UHPC) with compressive strength higher than $80 \mathrm{MPa}$ needs to rely on the results of push-out test using such concrete. Accordingly, this study performs push-out test on mixes with compressive strengths of $80 \mathrm{MPa}$ and $180 \mathrm{MPa}$, and compares the experimental results with the predictions of the previous models.

\subsection{Test Variables and Material Properties}

The basic dimensions of the perfobond rib are a thickness $(t)$ of $12 \mathrm{~mm}$, a height $(h)$ of $100 \mathrm{~mm}$, and a length $(L)$ of $310 \mathrm{~mm}$. The considered test variables arranged in Table 2 are the number of holes and their diameter. For each test variable, two series of specimens were fabricated using two types of concrete with respective block compressive strength of $80 \mathrm{MPa}$ and $180 \mathrm{MPa}$. The 180-MPa perfobond specimens were fabricated using UHPC reinforced with steel fiber at a ratio of $1.5 \%$ and exhibited a mean compressive strength of about 176.9 MPa in the cylinder test. The 80-MPa perfobond specimens were fabricated using high strength concrete mixed with 20$\mathrm{mm}$ coarse aggregate and blast furnace slag and without steel fiber reinforcement. These specimens developed a mean compressive strength of approximately $80.1 \mathrm{MPa}$ in the cylinder test.

\subsection{Test Method}

Loading was applied stepwise by displacement control under initial application of a load of $5 \mathrm{kN}$ for stabilization. The loading range and speed at each loading stage are listed in Table 3.

The measurands of the tests are the relative slip between the steel girder and the concrete block measured at 2 spots in the front face and 2 spots in the rear face, the horizontal displacement of the concrete blocks measured at each center of the two blocks, and the vertical displacement of the steel girder measured at 1 spot at the center of the girder. Figure 4 shows the layout of the 7 displacement sensors installed on the specimen. Figure 5 presents scenes of the test setup.

\subsection{Test Results}

Figure 6 and Figure 7 plot the load-relative slip curves for each specimen. For the comparison of the shear strengths obtained experimentally and from the prediction models, the characteristic load $\left(P_{r k}\right)$ is calculated as

Table 2. Test variables of perfobond rib specimens.

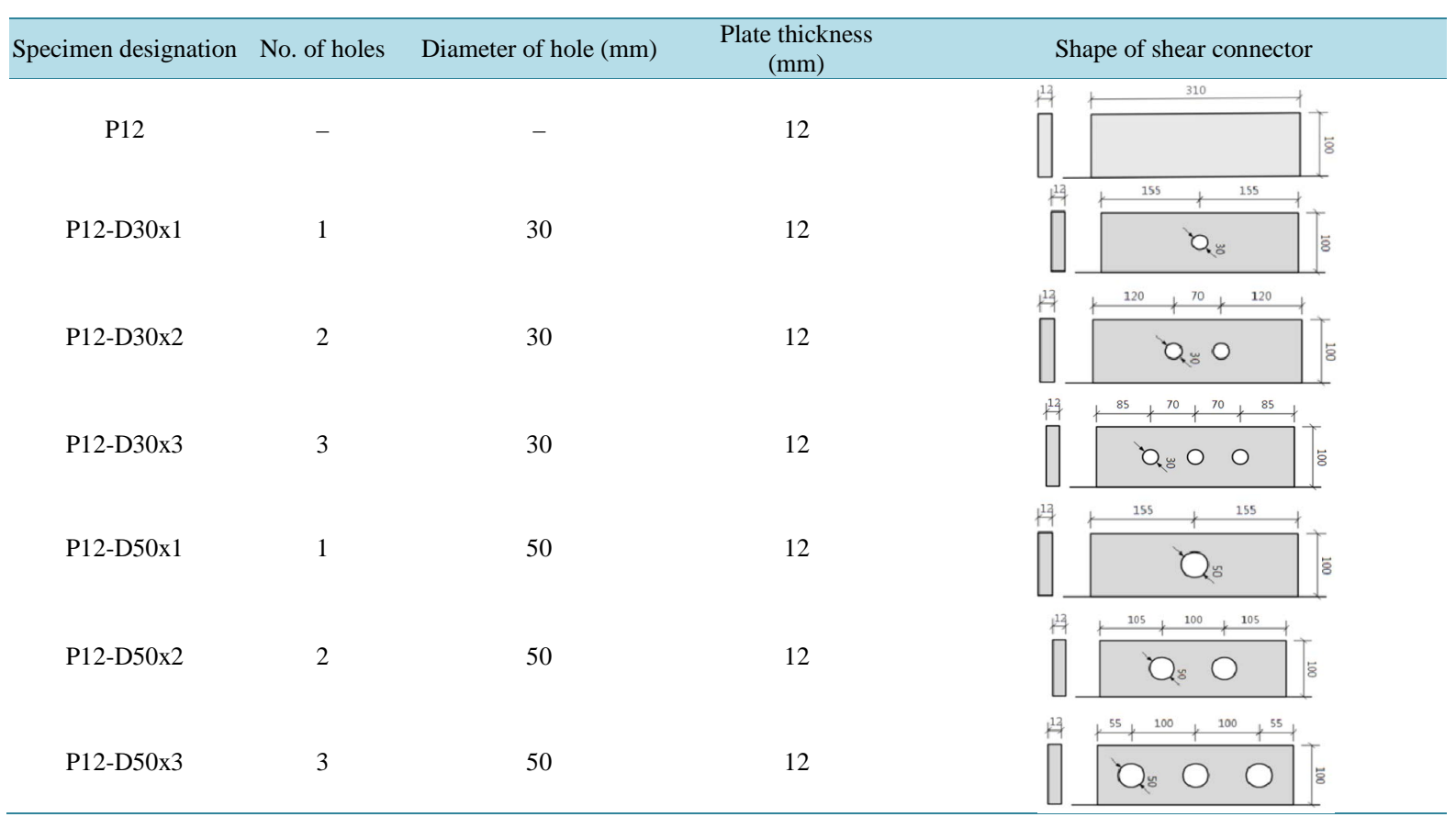


Table 3. Loading range and speed per loading stage of push-out test.

\begin{tabular}{cccc}
\hline Loading stage & Loading range & Loading speed $(\mathrm{mm} / \mathrm{s})$ & Remarks \\
\hline Stage 1 & $5 \mathrm{kN}$ & - & Stabilization load (zeroing) \\
Stage 2 & $3 \mathrm{~mm}$ & 0.004 & - \\
Stage 3 & $6 \mathrm{~mm}$ & 0.006 & - \\
Stage 4 & $10 \mathrm{~mm}$ & 0.01 & - \\
Stage 5 & $20 \mathrm{~mm}$ & 0.04 & - \\
Stage 6 & $>20 \mathrm{~mm}$ & 0.06 & Until failure \\
\hline
\end{tabular}
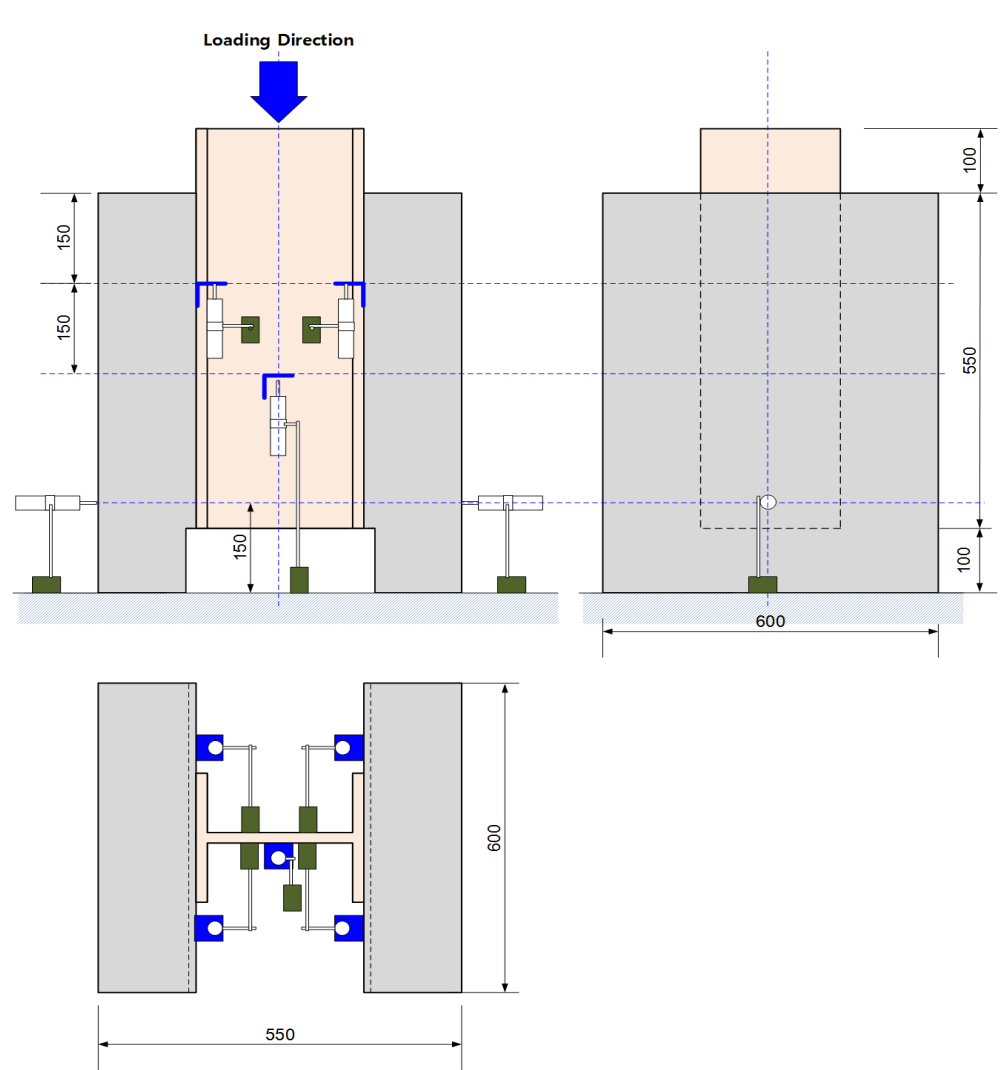

Figure 4. Layout of displacement sensors.
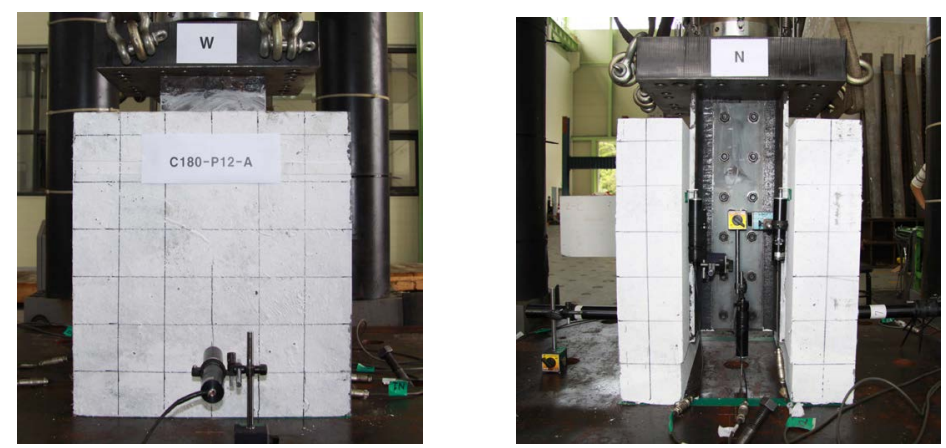

Figure 5. Views of push-out test: front (left), rear (right).

90\% of the ultimate load $\left(P_{u}\right)$ based on Eurocode. Table 4 arranges the experimental results for each specimen.

The results are rearranged in Figure 8 in which the shear strength is seen to increase with larger number of holes and higher compressive strength of concrete. Larger diameter of the holes appears to enlarge the dowel ac- 


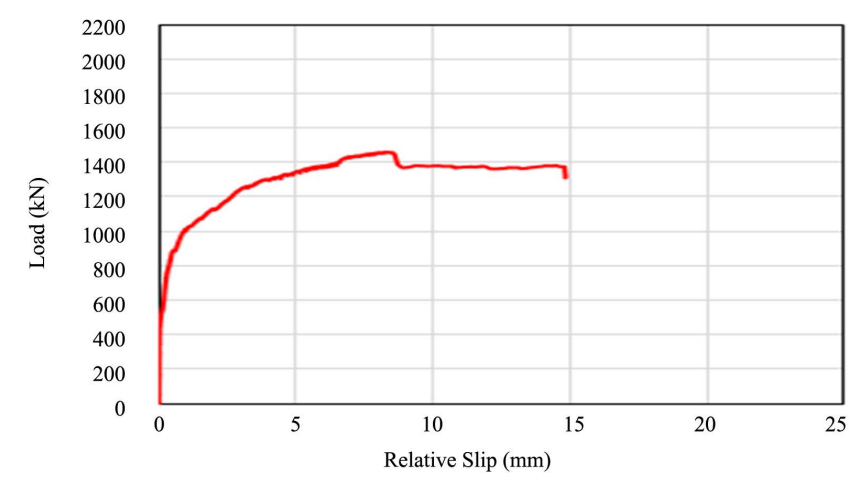

(a)

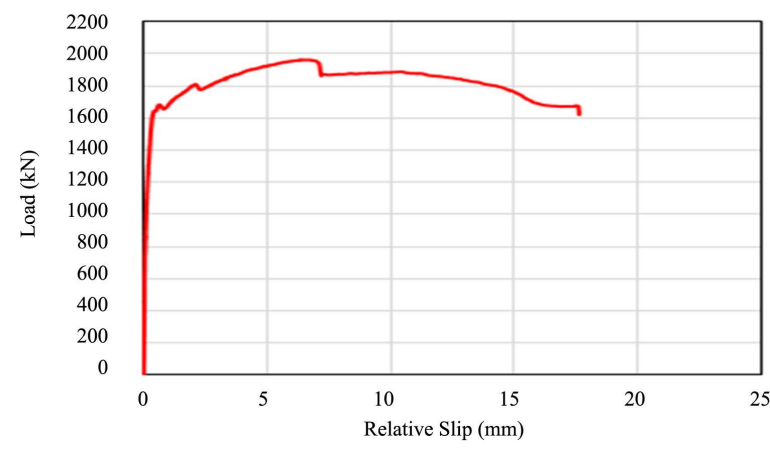

(b)

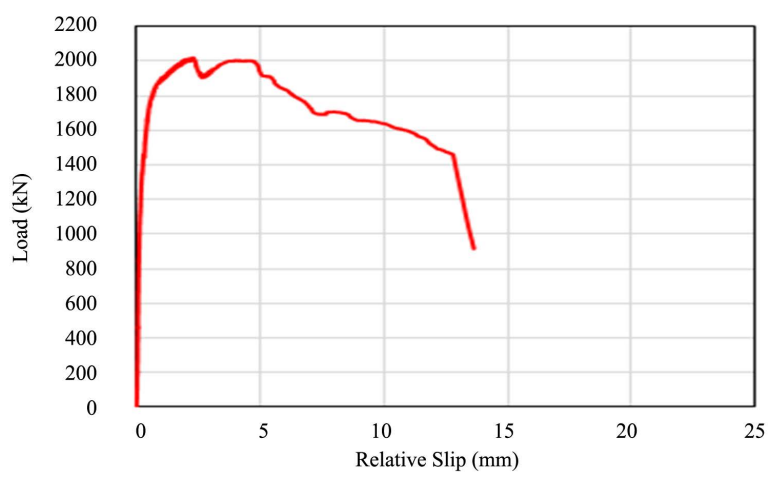

(d)

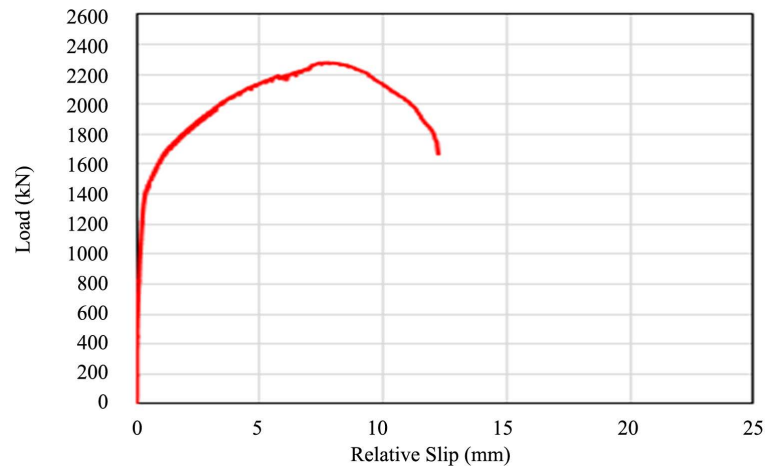

(f)

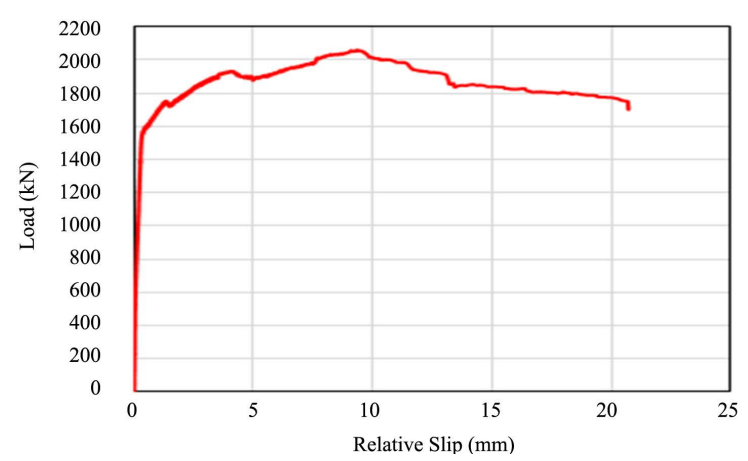

(c)

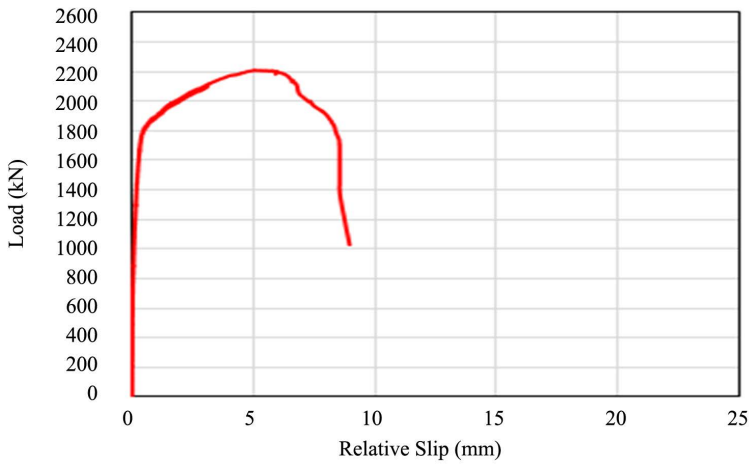

(e)

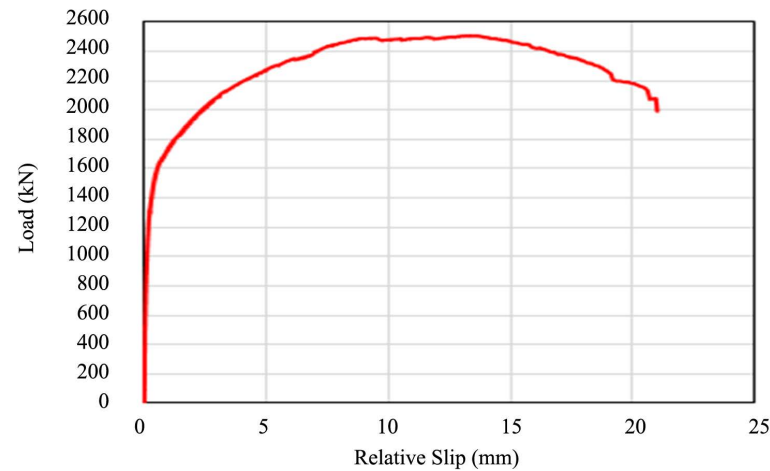

(h)

Figure 6. Measured load-relative slip curves (180-MPa perfobond rib specimens, load per 2 perfobond ribs). (a) C180-P12; (b) C180-P12-D30x1; (c) C180-P12-D30x2; (d) C180-P12-D30x3; (e) C180-P12-D50x1; (f) C180-P12-D50x2; (g) C180P12-D50x3. 


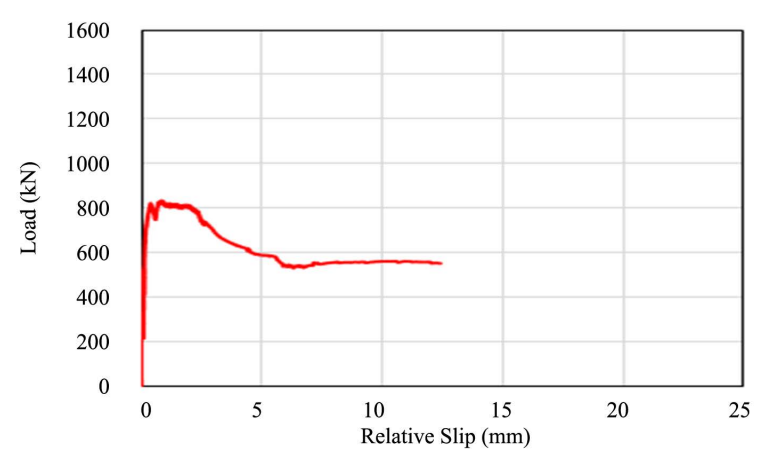

(a)

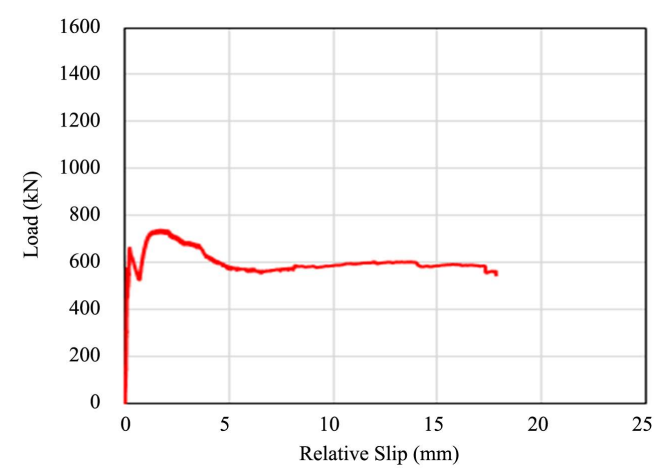

(b)

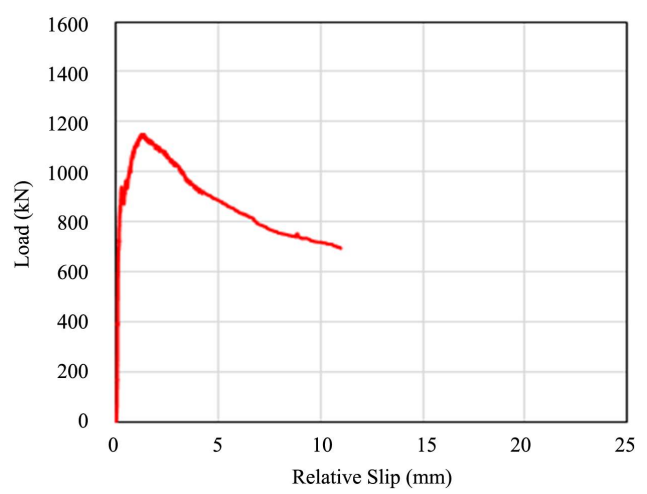

(d)

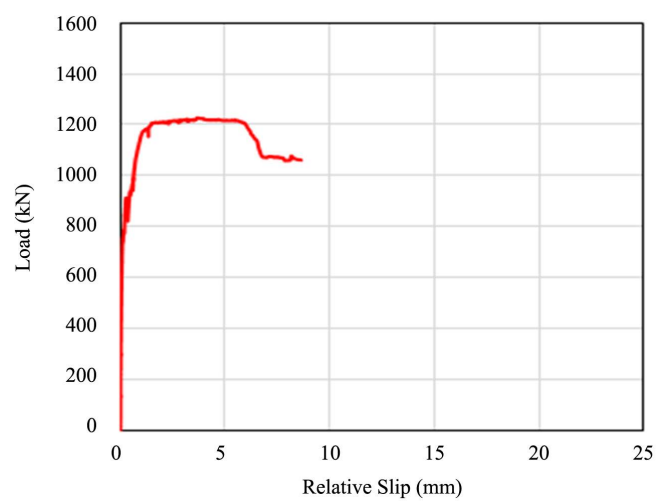

(f)

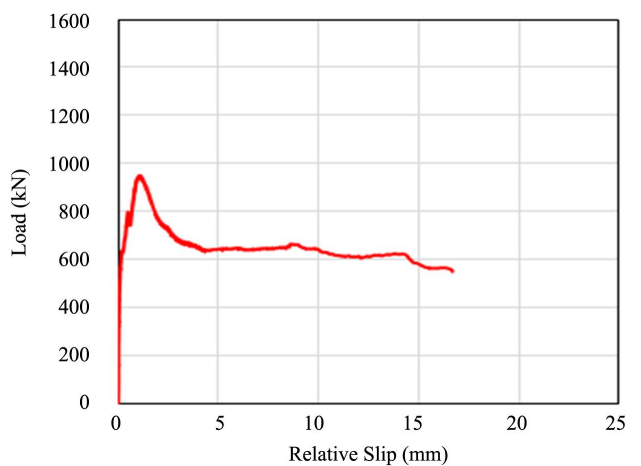

(c)

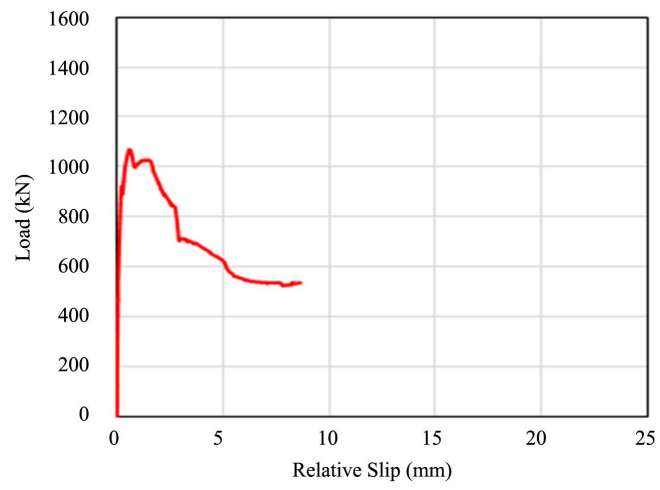

(e)

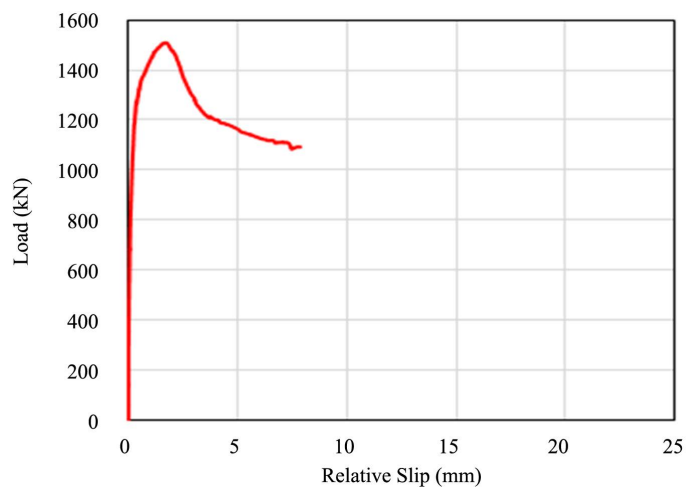

(h)

Figure 7. Measured load-relative slip curves (80-MPa perfobond rib specimens, load per 2 perfobond ribs). (a) C80-P12; (b) C80-P12-D30x1; (c) C80-P12-D30x2; (d) C80-P12-D30x3; (e) C80-P12-D50x1; (f) C80-P12-D50x2; (g) C80-P12-D50x3. 


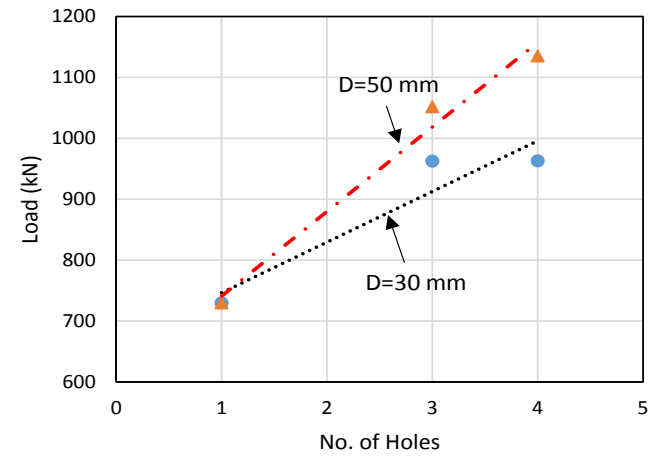

(a)

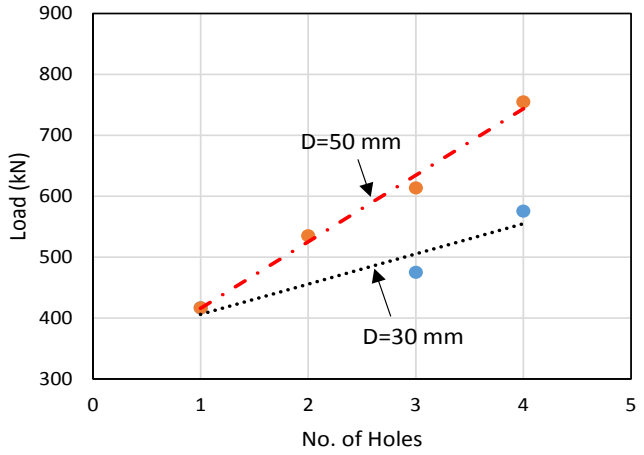

(b)

Figure 8. Change in shear strength according to number of holes. (a) 180-MPa strength; (b) 80-MPa strength.

Table 4. Push-out test results of perfobond rib specimens using high strength concretes.

\begin{tabular}{|c|c|c|c|c|c|c|c|c|}
\hline \multirow{2}{*}{ Specimens } & \multirow{2}{*}{$\begin{array}{l}\text { Concrete } \\
\text { strength } \\
(\mathrm{MPa})\end{array}$} & \multirow{2}{*}{ No. of holes } & \multirow{2}{*}{$\begin{array}{l}\text { Diameter of } \\
\text { hole }(\mathrm{mm})\end{array}$} & \multirow{2}{*}{$\begin{array}{l}\text { Ultimate load, } \\
\qquad P_{u}(\mathrm{kN})\end{array}$} & \multirow{2}{*}{$\begin{array}{l}\text { Relative slip, } \\
\delta_{u}(\mathrm{~mm})\end{array}$} & \multicolumn{2}{|c|}{ Characteristic values } & \multirow{2}{*}{$\begin{array}{l}\text { Ductility, } \\
\delta_{u k} / \delta_{u}\end{array}$} \\
\hline & & & & & & Load, $P_{r k}(\mathrm{kN})$ & $\begin{array}{l}\text { Relative slip, } \delta_{u k} \\
\text { (mm) }\end{array}$ & \\
\hline C180-P12 & & - & - & 730.0 & 8.34 & 657.0 & 14.38 & 1.78 \\
\hline C180-P12-D30x1 & & 1 & 30 & 1011.0 & 6.57 & 909.9 & 14.93 & 2.27 \\
\hline C180-P12-D30x2 & & 2 & 30 & 962.3 & 9.34 & 866.1 & 13.22 & 1.42 \\
\hline C180-P12-D30x3 & 180 & 3 & 30 & 963.0 & 2.29 & 866.7 & 6.18 & 2.70 \\
\hline C180-P12-D50x1 & & 1 & 50 & 1032.3 & 5.05 & 929.1 & 7.38 & 1.46 \\
\hline C180-P12-D50x2 & & 2 & 50 & 1051.8 & 7.76 & 946.6 & 10.70 & 1.37 \\
\hline C180-P12-D50x3 & & 3 & 50 & 1135.0 & 13.46 & 1021.5 & 19.03 & 1.41 \\
\hline C80-P12 & & - & - & 416.6 & 0.84 & 374.9 & 2.47 & 2.95 \\
\hline C80-P12-D30x1 & & 1 & 30 & 368.8 & 1.76 & 331.9 & 3.61 & 2.05 \\
\hline C80-P12-D30x2 & & 2 & 30 & 474.9 & 1.04 & 427.4 & 1.59 & 1.53 \\
\hline C80-P12-D30x3 & 80 & 3 & 30 & 575.3 & 1.32 & 517.8 & 1.48 & 1.12 \\
\hline C80-P12-D50x1 & & 1 & 50 & 535.0 & 0.61 & 481.5 & 1.82 & 2.98 \\
\hline C80-P12-D50x2 & & 2 & 50 & 613.7 & 3.68 & 552.3 & 6.62 & 1.80 \\
\hline C80-P12-D50x3 & & 3 & 50 & 754.7 & 1.73 & 679.2 & 2.57 & 1.30 \\
\hline
\end{tabular}

tion, which in turn accentuates the tendency of the shear strength to increase. Furthermore, higher strength of concrete also promotes the increase of the shear strength by the dowel action. Here, specimen C80-P12-D30x1 applying 80-MPa concrete and with one dowel hole was expected to develop higher shear strength than specimen C80-P12 without hole but exhibited contrarily reduced shear strength. This result can be attributed to some problem in the fabrication of the specimen.

\section{Comparison of Test Results and Previous Prediction Models}

In order to verify the applicability of previous models for the prediction of the shear strength of UHPC exhibiting higher strength than conventional concrete, Table 5 compares the experimental results to the shear strength predicted by these models. It can be observed that the experimental results approach well the predictions of the shear strength given by the model proposed by Oguejiofor and Hosain [1] and that the predictions of the model proposed by Medberry and Shahrooz [2] differ from the test results by maximum 2.33 times.

Figure 9 and Figure 10 compare the increase pattern of the ultimate shear load of the test results to the shear strength curves provided by the previous prediction models. Here also, the model proposed by Oguejiofor and Hosain [1] approaches closely the test results. In Figure 9, the test results for the cases applying 2 and 4 headed studs are plotted concurrently. Their respective shear forces are $377.1 \mathrm{kN}$ and $780.3 \mathrm{kN}$. This indicates that the 


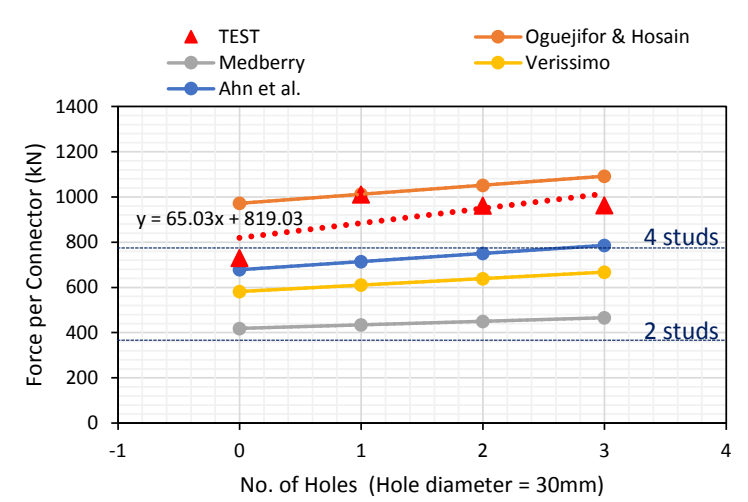

(a)

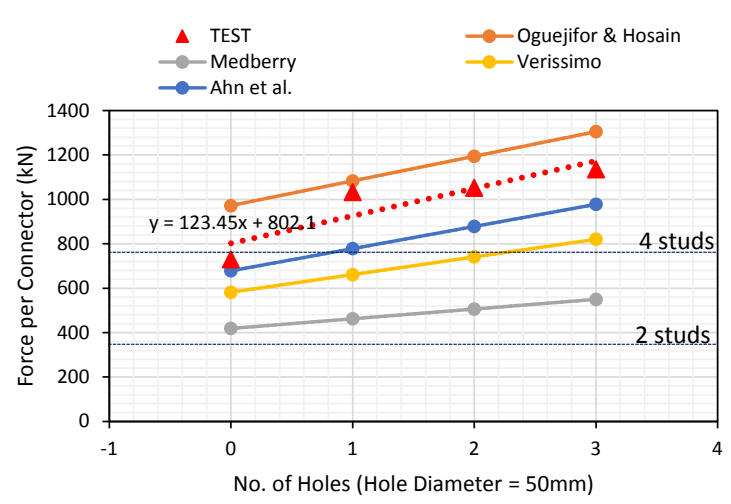

(b)

Figure 9. Comparison of shear prediction models (180-MPa concrete). (a) $D=30 \mathrm{~mm}$; (b) $D=50 \mathrm{~mm}$.

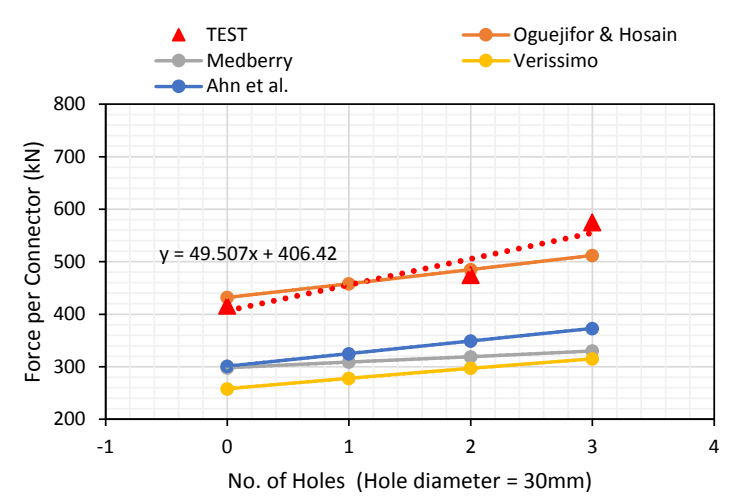

(a)

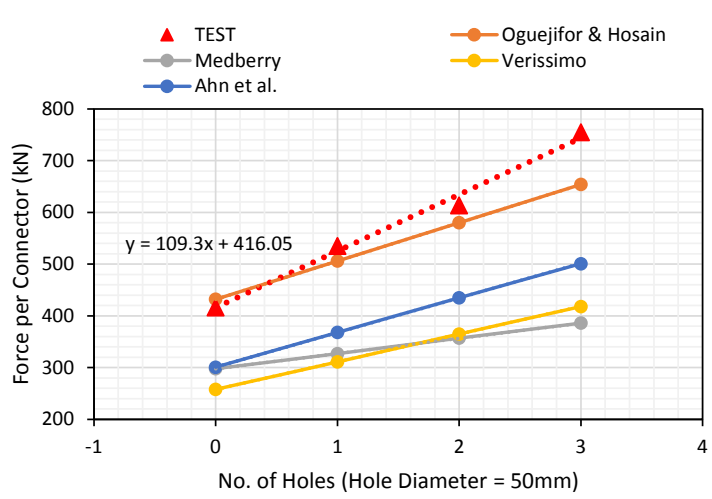

(b)

Figure 10. Comparison of shear prediction models (80-MPa concrete). (a) $D=30 \mathrm{~mm}$; (b) $D=50 \mathrm{~mm}$.

Table 5. Comparison of experimental and predicted shear capacities.

\begin{tabular}{|c|c|c|c|c|c|c|c|c|c|}
\hline \multirow[b]{2}{*}{ Specimens } & \multicolumn{5}{|c|}{ Shear capacity per connector (kN) } & \multirow[b]{2}{*}{ Test/(1) } & \multirow[b]{2}{*}{ Test/(2) } & \multirow[b]{2}{*}{ Test/(3) } & \multirow[b]{2}{*}{ Test/(4) } \\
\hline & Test & $\begin{array}{l}\text { Oguejiofor et al. } \\
\text { (1) }\end{array}$ & $\begin{array}{l}\text { Medberry et al. } \\
\text { (2) }\end{array}$ & $\begin{array}{l}\text { Verissimo et al. } \\
\text { (3) }\end{array}$ & Ahn et al. (4) & & & & \\
\hline C180-P12 & 730.0 & 972 & 419 & 582 & 678 & 0.75 & 1.74 & 1.25 & 1.08 \\
\hline C180-P12-D30x1 & 1011.0 & 1012 & 434 & 610 & 714 & 1.00 & 2.33 & 1.66 & 1.42 \\
\hline C180-P12-D30x2 & 962.3 & 1052 & 450 & 639 & 750 & 0.91 & 2.14 & 1.51 & 1.28 \\
\hline C180-P12-D30x3 & 963.0 & 1092 & 466 & 668 & 786 & 0.88 & 2.07 & 1.44 & 1.23 \\
\hline C180-P12-D50x1 & 1032.3 & 1083 & 462 & 661 & 778 & 0.95 & 2.23 & 1.56 & 1.33 \\
\hline C180-P12-D50x2 & 1051.8 & 1194 & 506 & 741 & 878 & 0.88 & 2.08 & 1.42 & 1.20 \\
\hline C180-P12-D50x3 & 1135.0 & 1305 & 550 & 820 & 978 & 0.87 & 2.06 & 1.38 & 1.16 \\
\hline C80-P12 & 416.6 & 432 & 298 & 258 & 301 & 0.96 & 1.40 & 1.61 & 1.38 \\
\hline C80-P12-D30x1 & 368.8 & 458 & 309 & 278 & 325 & 0.81 & 1.19 & 1.33 & 1.13 \\
\hline C80-P12-D30x2 & 474.9 & 485 & 319 & 297 & 349 & 0.98 & 1.49 & 1.60 & 1.36 \\
\hline C80-P12-D30x3 & 575.3 & 512 & 330 & 315 & 373 & 1.12 & 1.74 & 1.83 & 1.54 \\
\hline C80-P12-D50x1 & 535.0 & 506 & 327 & 311 & 368 & 1.06 & 1.64 & 1.72 & 1.45 \\
\hline C80-P12-D50x2 & 613.7 & 580 & 357 & 365 & 435 & 1.06 & 1.72 & 1.68 & 1.41 \\
\hline C80-P12-D50x3 & 754.7 & 654 & 386 & 418 & 501 & 1.15 & 1.96 & 1.81 & 1.51 \\
\hline
\end{tabular}

perfobond rib specimen C180-P12 without dowel hole develops shear strength comparable to the case applying 4 headed studs, and means that one perfobond rib provides a level of shear strength sufficient to replace 4 headed studs. 
The specimens using concrete with compressive strength of $180 \mathrm{MPa}$ in Figure 9 are seen to develop shear strength lower by about $10 \%$ than that calculated by the prediction formula of Oguejiofor and Hosain [1]. The increase rate of the shear strength shows similar trend to the predictions according to the number of dowel holes. The specimens applying concrete with compressive strength of $80 \mathrm{MPa}$ in Figure 10 develop shear strength larger by $5 \%$ to $15 \%$ than the predictions. Larger difference in the shear strength can be observed compared to the predictions as much as the number of dowel holes increases.

Moreover, in all cases, the increase rate of the shear strength caused by the dowel action augmented with larger diameter of the dowel hole regardless of the compressive strength of concrete. The enlargement of the diameter of the holes appears to have larger influence on the increase of the dowel action in case of low compressive strength.

\section{Conclusions}

This study conducted push-out test to measure the shear strength of the perfobond rib connector in ultra high performance concrete member with compressive strength of $80 \mathrm{MPa}$ and $180 \mathrm{MPa}$ and compared the results with those of previous prediction models. The test results revealed that the concrete dowel action provided by the holes of the perfobond rib did not show clear difference in the shear strength for the 180-MPa specimens whereas clear increase of the shear strength occurred owing to the dowel action in the 80-MPa specimens.

The comparison with the increase trend of the shear strength obtained by the prediction models indicated that the experimental results could be predicted using these models within their prediction range. Among these models, the formula proposed by Oguejiofor and Hosain [1] provided the most accurate predictions, and the model proposed by Ahn et al. [5] was seen to be conservative.

Considering the small number of specimens adopted in this study, it is presumptuous to suggest a model covering the strength range of ultra high performance concrete. However, the comparison of the previous shear strength prediction models enabled to assess the models applicable in design. It is expected that a shear strength prediction model for perfobond rib using ultra high performance concrete could be proposed through further tests considering diversified compressive strengths ranging between 80 and $180 \mathrm{MPa}$.

\section{Acknowledgements}

This study was supported financially through the project "Development of SUPER Concrete with compressive strength of 80 - $180 \mathrm{MPa}$ and its application (1st year)”. The authors express their gratitude for the support.

\section{References}

[1] Ushijima, Y., Hosaka, T., Mitsuki, K., Watanabe, H., Tachibana, Y. and Hiragi, H. (2001) An Experimental Study on Shear Characteristics of Perfobond Strip and Its Rational Strength Equations. Proceedings of the International Symposium on Connections between Steel and Concrete, Stuttgart, 10-12 September 2001, 1066-1075.

[2] Cho, J.R., Park, S.Y., Cho, K., Kim, S.T. and Kim, B.S. (2012) Pull-Out Test and Discrete Spring Model of Fibre-Reinforced Polymer Perfobond Rib Shear Connector. Canadian Journal of Civil Engineering, 39, 1311-1320. http://dx.doi.org/10.1139/cjce-2011-0573

[3] Oguejiofor, E.C. and Hosain, M.U. (1994) A Parametric Study of Perfobond Rib Shear Connectors. Canadian Journal of Civil Engineering, 21, 614-625. http://dx.doi.org/10.1139/194-063

[4] Medberry, S.B. and Shahrooz, B.M. (2002) Perfobond Shear Connector for Composite Construction. Engineering Journal, 39, 2-12.

[5] Verissimo, G.S., Valente, M.I.B., Paes, J.L.R., Cruz, P.J.S. and Fakury, R.H. (2006) Design and Experimental Analysis of a New Shear Connector for Steel and Concrete Composite Structures. Proceedings of the 3rd International Conference on Bridge Maintenance, Safety and Management, Porto, 16-19 July 2006, 68-72.

[6] Al-Darzi, S.Y.K., Chen, A.R. and Liu, Y.Q. (2007) Finite Element Simulation and Parametric Studies of Perfobond Rib Connector. Iraqi Virtual Science Library (www.ivsl.org). American Journal of Applied Sciences, 4, 122-127. http://dx.doi.org/10.3844/ajassp.2007.122.127

[7] Ahn, J.H., Lee, C.G., Won, J.H. and Kim, S.H. (2010) Shear Resistance of the Perfobond-Rib Shear Connector Depending on Concrete Strength and Rib Arrangement. Journal of Constructional Steel Research, 66, 1295-1307. http://dx.doi.org/10.1016/j.jcsr.2010.04.008

[8] An, L. and Cederwall, K. (1996) Push-Out Tests on Studs in High Strength and Normal Strength Concrete. Journal of 
Constructional Steel Research, 36, 15-29. http://dx.doi.org/10.1016/0143-974X(94)00036-H

[9] Hegger, J., Gallwoszus, J. and Rauscher, S. (2009) Load-Carrying Behaviour of Connectors under Shear, Tension and Compression in Ultra High Performance Concrete. NSCC2009 Report, RWTH Aachen University, Institute of Structural Concrete, Aachen. 
Scientific Research Publishing (SCIRP) is one of the largest Open Access journal publishers. It is currently publishing more than 200 open access, online, peer-reviewed journals covering a wide range of academic disciplines. SCIRP serves the worldwide academic communities and contributes to the progress and application of science with its publication.

Other selected journals from SCIRP are listed as below. Submit your manuscript to us via either submit@scirp.org or Online Submission Portal.
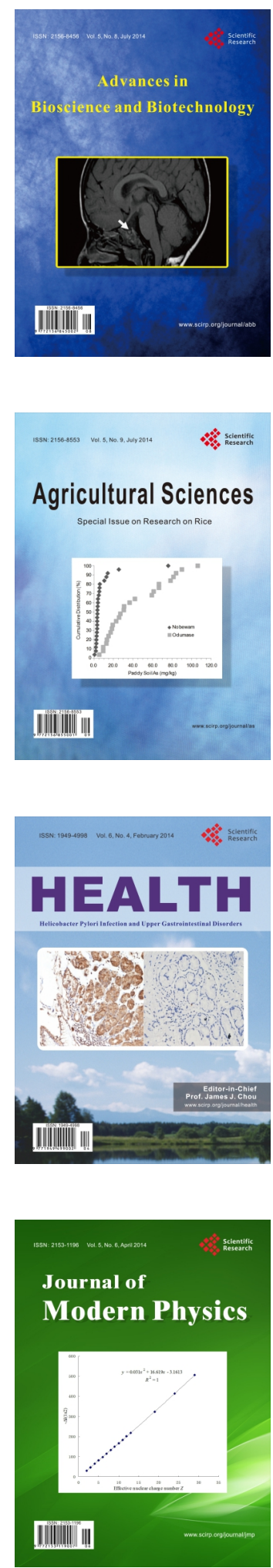
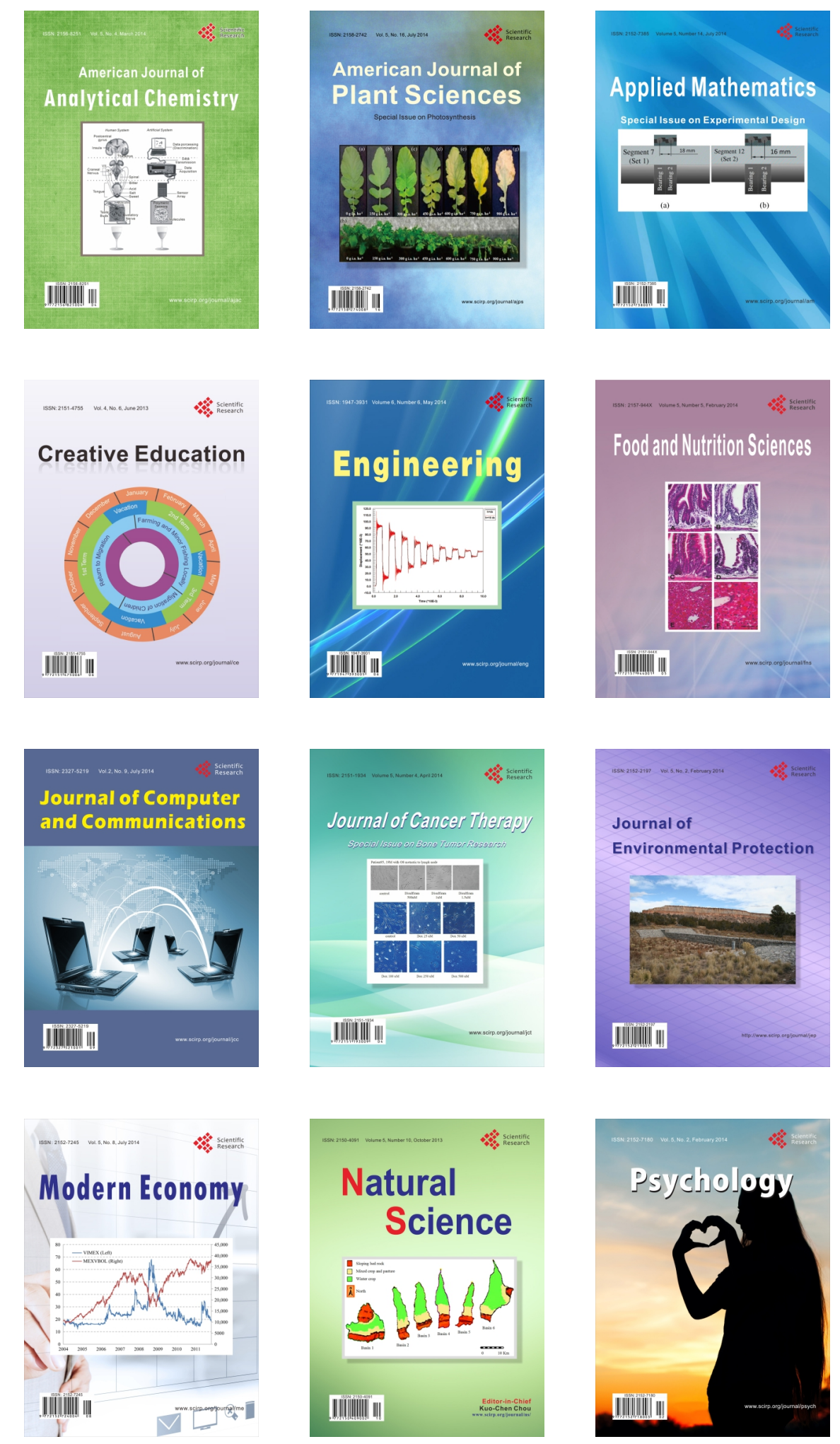